\title{
„Neue Marktforschung"
}

Literaturhinweise zusammengestellt von Dipl.-Kffr. Liane Nagengast

Bücher:

Backhaus, K./Erichson, B./Plinke, W./

Weiber, R. (2008)

Multivariate Analysemethoden, 12. Aufl., Berlin.

Buber, R./Holzmüller, H. H. (2007)

Qualitative Marktforschung: Konzepte -

Methoden - Analysen, Wiesbaden.

Diller, H. (2008)

Web 2.0: Hype oder Substanz, Nürnberg.

Duchowski, A. T. (2007)

Eye Tracking Methodology: Theorie and Practice, 2. Aufl., London.

Häusel, H. G. (2004)

Brain Script, München.

Häusel, H. G. (Hrsg.) (2007)

Neuromarketing: Erkenntnisse der Hirnforschung für Markenführung, Werbung und Verkauf, München.

Heidel, B. (2008)

Lexikon Konsumentenverhalten und

Marktforschung, Frankfurt.

Hermann, A./Homburg, C./Klarmann, M.

(Hrsg.) (2008)

Handbuch Marktforschung: Methoden - Anwendungen - Praxisbeispiele, 3. Aufl., Wiesbaden.

Gröppel-Klein, A. (Hrsg.) (2004)

Konsumentenverhaltensforschung im

21. Jahrhundert, Wiesbaden.

Kuß, A. (2007)

Marktforschung: Grundlagen der Datenerhebung und Datenanalyse, 2. Aufl., Wiesbaden.

Rutschmann, M. (2005)

Kaufprozesse von Konsumenten erkennen und lenken: mehr Marktanteil mit neuem Marketing, Heidelberg.

Scheier, C./Held, D. (2006)

Wie Werbung wirkt: Erkenntnisse des Neuromarketings, Berlin.

Tashakkori, A./Teddlie, C. (Hrsg.) (2003)

Handbook of Mixed Methods in Social \&

Behavioral Research, Thousand Oaks.
Theobald, A. (2000)

Das World Wide Web als Befragungsinstrument, Wiesbaden.

Theobald, A./Dreyer, M./Strasetzki, T. (Hrsg.) (2001)

Online-Marktforschung: Theoretische Grundlagen und praktische Erfahrungen, Wiesbaden.

Zaltman, G. (2003)

How Customers Think: Essential Insights into the Mind of the Market, Boston.

\section{Artikel/Zeitschriften:}

Baker, S./Mouncey, P. (2003)

The market researcher's manifesto, in: International Journal of Market Research, 45, 4, S. 415-433.

Catterall, M./Maclaran, P. (2001)

Researching consumers in virtual worlds:

A cyberspace odyssey, in: Journal of Consumer Behaviour, 3, 1, S. 228-237.

Cooke, M./Buckley, N. (2008)

Web 2.0, social networks and the future of market research, in: The market research society, 50, 2, S. 267-292

Esch, F.-R./Möll, T./Elger, C. E./Neuhaus, C./ Weber, B. (2008)

Wirkung von Markenemotionen: Neuromarketing als neuer verhaltenswissenschaftlicher Zugang, in: Marketing - ZFP, 30, 2, S. 199-122.

Füller, J./Kohler, T./Stieger, D./Matzler, K. (2008) Marktforschung. Trendsuche mit Online-Spielen, in: Harvard Business Manager, 30, 7, S. 22-30.

Hubert, M./Kenning, P. (2008)

A current overview of consumer neuroscience, in: Journal of Consumer Behaviour, 7, 4/5, S. 272-292.

Ilieva, J./Baron, S./Healey, N. M. (2002) Online surveys in marketing research: pros and cons, in: International Journal of Market Research, 44, 3, S. 361-376

Kenning, P./Plassmann, H./Ahlert, D. (2007) Consumer Neuroscience. Implikationen neurowissenschaftlicher Forschung für das Marketing, in: Marketing - ZFP, 29, 1, S. 57-68.

Kenning, P./Plassmann, H./Ahlert, D. (2007)

Application of Neuroimaging Techniques to Marketing Research, in: Qualitative Market Research, 10, 2, S. 135-152.
Keselman, H. J./Algina, J./Kowalchuk, R. K. (2001) The Analysis of Repeated Measures Designs: a Review, in: British Journal of Mathematical and Statistical Psychology, 54, S. 1-20.

Kozinets, R. (2002)

The Field Behind the Screen: Using Netnography for Marketing Research, in: Online Communities, in: Journal of Marketing Research, 39, 1, S. 61-72.

LaTour, S. A./Miniard, P. W. (1983)

The Misuse of Repeated Measures Analysis in Marketing Research, in: Journal of Marketing Research, 20, 1, S. 45-57.

Lipner, W. (2007)

The Future of Online Market Research, in: Journal of Advertising Research, 47, 2, S. 142-146.

Malhotra, N. K./Peterson, M. (2001)

Marketing Research in the new millennium: emerging issues and trends, in: Marketing Intelligence and Planning, 19, 4, S. 216-235.

Montoya-Weiss, M. M./Massey, A. P./Qapper, D. L. (1998)

On-line focus groups: conceptual issues and a research tool, in: European Journal of Marketing, 32, 7/8, S. 713-723.

Ortt, R. J./Schoormans, J. P. L. (1993)

Consumer Research in the development process of a major innovation, in: Journal of the Marketing Research Society, 35, 4, S. 375-388.

Perrachione, T. K./Perrachione, J. R. (2008)

Brains and brands: developing mutually informative research in neuroscience and marketing, in: Journal of Consumer Behaviour, 7, 4/5, S. 303-318.

Puri, A. (2007)

The web of insights, in: International Journal of Market Research, 49, 3, S. 387-408.

Zaltman, G. (1997)

Rethinking Market Research: Putting People Back in, in: Journal of Marketing Research, 34, 4,

S. 424-437. 